\title{
Record of rust diseases of the Chrysanthemum, Gladiolus and Limonio in the Cochabamba Valley, Bolivia
}

\section{Coca Morante $\mathbf{M}^{1^{*}}$}

${ }^{1}$ Plant pathology laboratory. Departamento de fitotecnia y producción vegetal. Facultad de Ciencias Agrícolas y Pecuarias. Universidad Mayor de San Simón. Cochabamba, Bolivia

\begin{abstract}
Flower production is an important economic activity in the Cochabamba Valley, Bolivia. Species and varieties of Roses (Rosa sp-), Chrysanthemums (Chrysantemum sp.), Carnations (Dianthus carophyllus), Gladiolus (Gladiolus communis), Saticias (Limonium sp.), Liliums (Liliums sp.,) etc. are grown. Rusts affect a variety of crops, including flowers. The aim of this study, was identify the rust diseases that is affecting to three important flower species. Stems and leaves of samples with characteristic rust symptoms of smallholder farmer parcels were collected between 2016 and 2018 of the Chrysantemum grandiflorum, G. communis and Limonium sp. Based on morphometric studies the causal agent of rust diseases was identify as the first record to Puccinia horiana on chrysanthemum, Uromyces transversalis on Gladiolus and Uromyces limonii on Limonio in the Cochabamba Valley, Bolivia.
\end{abstract}

Keywords: Fungi; Rust; Uredinales

\section{INTRODUCTION}

The Bolivian Inter Andean Valleys (2000 - 3000 meters above sea level), due to its favorable weather, soil conditions and water availability, are suitable for the vegetables and flowers production. Currently, in the Central and Lower Cochabamba Valley of department, Bolivia, flower production is an important economic activity. Species and varieties of Roses (Rosa sp-), Chrysanthemums (Chrysantemum sp.), Carnations (Dianthus carophyllus), Gladiolus (Gladiolus communis), Saticias (Limonium sp.), Liliums (Liliums sp.,) etc. are grown for the local market and a small part for export. Smallholder farmers mostly grown in the "open field" and for export are grown under cover [1].

One of the limiting factors in the flowers production are the fungal diseases. Fungi, like rust disease, are destructive. Globally they are considered one of the most serious threats to agriculture [2]. Rusts affect a variety of crops, including flowers. According to Buritica et al, [3] in Colombia, rusts affect different flowers species and some such as Gladiolus rust is considered of plant quarantine in Europe and the United States [4]. At present rust affects several flowers species, they have widespread distribution and cause production losses in the Cochabamba Valley. However, there are only isolated reports of rust disease for
Bolivia. Otazu et al. in the "Plant diseases in Bolivia" reported only to carnation rust caused by Uromyces caryophyllinus [5]. The aim of this study, was identify the rust diseases that is affecting to three flower species by morphological details of urediniospores and teliospores collected from natural infections in the farmers' field in the Cochabamba Valley, Bolivia.

\section{MATERIALS AND METHODS}

Stems and leaves of samples with characteristic rust symptoms of smallholder farmer parcels were collected between 2016 and 2018 of the Chrysantemum grandiflorum, G. communis and Limonium sp. of the Cochabamba Valley (Municipalities of Tirani, Tiquipaya, Quillacollo, Vinto y Sipe Sipe). This valley, is delimited approximately by the following UTM-coordinates Latitude $8083000-8070000 \mathrm{~N}$ and Longitude $780000-800000$ $\mathrm{W}$, to $2550 \mathrm{msnm}$ altitude, 450 to $550 \mathrm{~mm}$ of rain and average annual temperature $17^{\circ} \mathrm{C}$, with a minimum of $5^{\circ} \mathrm{C}$ and maximum of $34 \mathrm{oC}$. The fungi causing rusts were identified examining pustules under a Stereomicroscope and urediniospores and teliospores formed in the pustules was examined Under Light Microscopic staining with lactophenol

*Correspondence to: Coca Morante M, Plant pathology laboratory. Departamento de fitotecnia y produccion vegetal. Facultad de Ciencias Agrícolas y Pecuarias. Universidad Mayor de San Simon. Cochabamba, Bolivia , Tel: +59144762383; E-mail: agr.mcm10@gmail.com

Received date: December 05, 2020; Accepted date: April 09, 2020; Published date: April 16, 2020

Citation: Coca MM (2020) Record of rust diseases of the Chrysanthemum, Gladiolus and Limonio in the Cochabamba Valley, Bolivia. Plant PatholMicrobiol. 11:493. doi: 10.35248/2157-7471.20.11.493.

Copyright: ( 2020 Coca MM, et al. This is an open-access article distributed under the terms of the Creative Commons Attribution License, which permits unrestricted use, distribution, and reproduction in any medium, provided the original author and source are credited. 
methylene blue using the taxonomic keys and indicators of different authors as indicated below.

\section{RESULTS AND DISCUSSION}

\section{Chrysanthemum rust}

The pustules were formed mostly on the lower side of the leaves (Figure 1A,B,C). On the leaves or stems were not found other spore state of the rust fungi. According to Hernandez et al. Spermogonia, aecia and uredinia unknown [6]. Telia hypophyllous, compact, yellowish, $2-3 \mathrm{~mm}$ diameter, often clustered in irregular pattern. The teliospores were thin walled, bicelled, pedicellate, pale yellow, oblong to oblong-clavate, 30-50 $\times 10-16 \mu \mathrm{m}$, slightly constricted at the septum, smooth; pedicel hyaline persistent, up to $45 \mu \mathrm{m}$ long (Figure 1D). According to Hernandez et al [4] and based on this morphometric studies the causal agent is Puccinia horiana Henn.
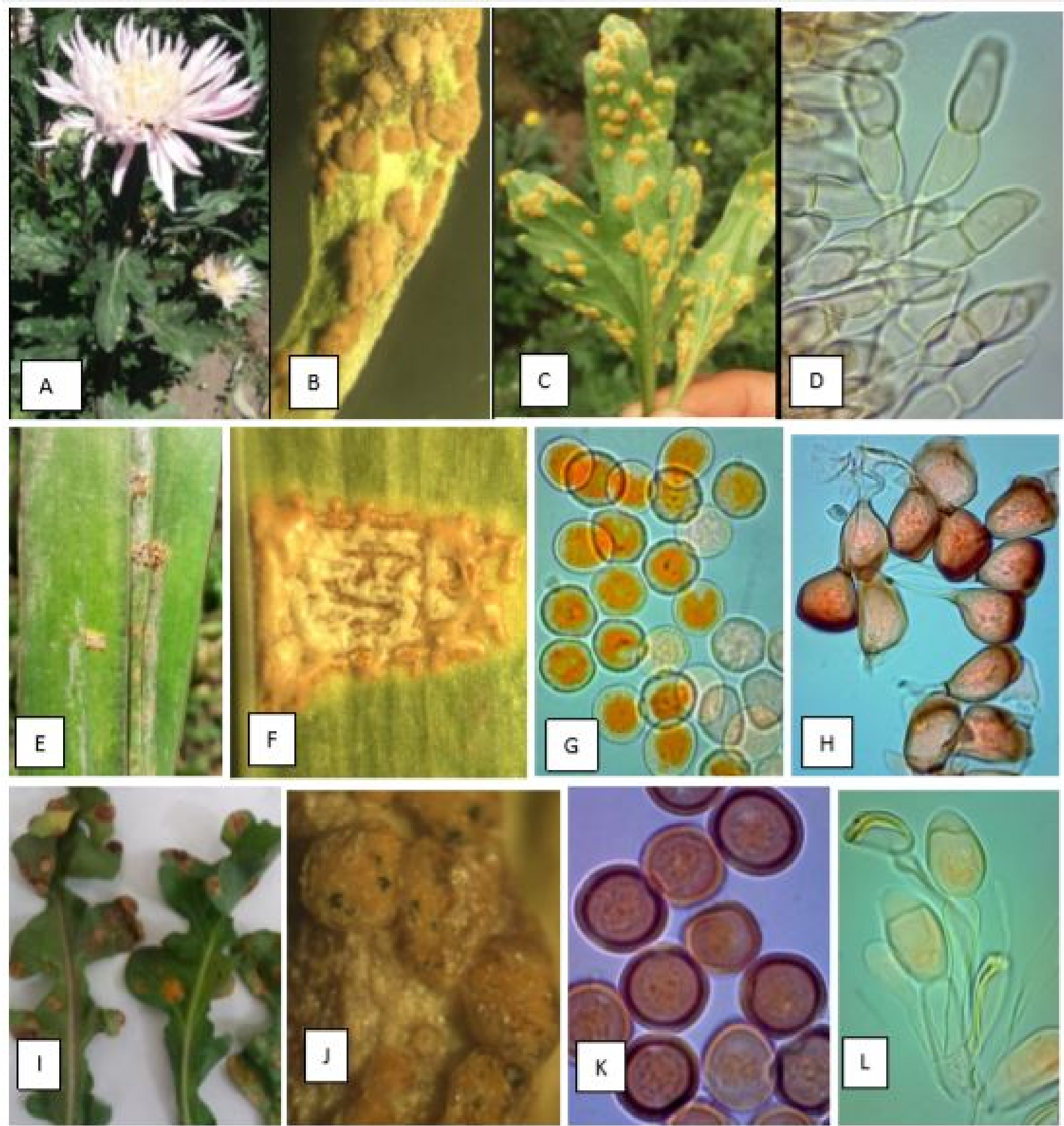

Figure 1: A: Chrysantemum rust pustules (Ch. grandiflorum) caused by P. horiana; B: Telia pustules deformming leaf; C: Pustules on leaf; D: Hyaline and bicelled teliospores (400X); E: Gladiolus rust pustules causaded by U. transversalis; F: Uredinia and telia Pustule; H: Unicelular urediniospores (400X); I: Unicelular teliospores (400X); I: Limonium rust (Limonium sp.) caused by Uromyces limonii, J: Uredinia pustules;K: Unicelular uredisnospores (400X); L: Unicelular teliospores with pedicels (400X). 


\section{Gladiolus rust}

The pustules are formed on the leaves, yellowish-orange, typically transverse (Figure 1E). Uredinia amphigenous, 0.5-3,5 $\mathrm{mm}$ long and $0.5-2 \mathrm{~mm}$ broad, sori at first covered by the blistered epidermis which finally splits (Figure 1F); urediniospores variable in form and size, globose, ovate, or oblong, 18-22 × 15-23 $\mu \mathrm{m}$, sub hyaline to yellowish-pale, cell wall hyaline, typically 1.3-2.5 $\mu \mathrm{m}$ thick, closely and minutely verruculose; germ pores obscure scattered (Figure 1G). Telia amphigenous, minute, black in small or larger lineal groups, remaining covered by the epidermis, which may be scattered, often grouped and loculate, separated by a zone of goldenbrown, palisade-like paraphyses, 50-112.5 $\mu \mathrm{m}$ diam., $55-75 \mu \mathrm{m}$ deep with spores in 3-4 closely packed rows (Figure 1F). Teliospores ovate, ellipsoid or pyriform, less frequently globose, often irregular or angular through mutual pressure, light brown, darker (often chestnut brown) near the apex, apex rounded, truncate or broadly conical, base usually attenuate, less frequently rounded; (17.5-) 20-25 (-34) × (14-) 15-17.5 (-21) $\mu \mathrm{m}$, cell wall smooth, usually $2 \mu \mathrm{m}$ thick, $4-6(-8) \mu \mathrm{m}$ at the apex; pedicel semipersistent, hyaline or tinted at the apex, $45 \mu \mathrm{m}$ long and $3 \mu \mathrm{m}$ thick (Figure $1 \mathrm{H}$ ). According to symptoms and uredinia and telia description is Uromyces transversalis (Thüm.). Spermogonia and aecia not was observed and according Hernandez et al. [4], this spore states are unknown.

\section{Limonium rust}

The pustules are formed on the leaves and stems, are yellowish and reddish-brown and irregular form (Figure 1I,J). Uredinia amphigenous, pulverulent and orange, $\mathrm{mm}$, sori at first covered by the blistered epidermis which finally burst (Fig. 1K). Uredionospores variable in form and size, ellipsoide or globose and minutely echinulate. Telia amphigenous similar to uredinia, black-brown (Figure $1 \mathrm{~K}$ ). Teliospores (22-28 $\mu \mathrm{m}$ length and 20-24 $\mu \mathrm{m}$ in wide) oblong to ellipsoid, unicellular, rarely ovate, color yellow-orange to light brown. the wall is light brown, smooth and thick or thicker at the top. The pedicel is hyaline $(50 \mu \mathrm{m})$ (Figure 1L). Spermagonia and Aecial phase not was observed and according Garcia-Hernandez et al. [7] this spore state are unknown. Therefore, based on this description and according to Garcia-Hernandez et al. [2] the causal agent is Uromyces limonii (D.C.) Lev. 1849.

\section{CONCLUSION}

These are the first record of the following rust disease affecting several species flowers, $P$. horiana on chrysanthemum, $U$. transversalis on Gladiolus, $U$. limonii on Limonium sp.in the Cochabamba Valley, Bolivia.

\section{REFERENCES}

1. Gente.Flores: International demand is high, but exports from Cochabamba fail to flourish. 2019.

2. Lorrain C, Goncalves dos Santos KC, Hugo G, Hecker A,Sebastien D. Advances in understanding obligate biotrophy in rust fungi. New Phytologist. 2018;222:1190-1206.

3. Buritica Cespedes P, Salazar YepesM.New fungi (uredinales) records potentially important in Colombia. RevFacNalAgrMedellin. 2007;60:3645-3655.

4. Hernández JR. Systematic Mycology and Microbiology Laboratory, ARS, USDA. 10 November 2004. Invasive Fungi. Gladiolus Rust. 2019.

5. Otazu V, Brown WM,de Quiton M. "Plant Diseases in Bolivia," Ministry of Rural and Agricultural Affairs / Bolivian Institute of Agricultural Technology / International Development Consortium, Cochabamba. 1982.

6. Hernández, J.R. Systematic Mycology and Microbiology Laboratory, ARS, USDA. 2004. Invasive Fungi. Chrysanthemum White Rust. 2019.

7. Garcia-Hernandez Pia D, Rojas-Jara M,Sepúlveda-Chavera GF. 2008. Presence of uromyceslimonii (dc) lév. (roya del limonium): first registry for the valle de lluta, region of arica and parinacota. Idesia. 2008;26:73-753. 